\title{
HUDEBNÍ KULTURA V KRNOVĚ DO POLOVINY 17. STOLETÍ
}

Hudební kultura období renesance na území zemí Koruny české představuje problematiku zpracovávanou v obecné rovině. Nicméně stále chybí plošné zmapování pramenné základny jednotlivých lokalit v Čechách, na Moravě i ve Slezsku, které by umožnilo syntetizující pohled a odkrylo provázanost jednotlivých lokalit i principů fungování hudby ve městech. Zvláště pro bádání v některých městských lokalitách ve Slezsku je nezbytný pramenný výzkum, při kterém jsou zohledněny jak prameny nehudební povahy, tak i doposud existující odborná literatura např́ič jednotlivými obory.

Formou sond jsou zmapovány lokality Český Krumlov, ${ }^{1}$ Praha $^{2}$ nebo Hlučín, ${ }^{3}$ které nabízejí mnohá metodologická východiska. V tomto př́spěvku jsou shromážděny informace o hudebním provozu, institucích a osobách spojených s hudebním děním v renesančním Krnově ${ }^{4}$ s přesahem do poloviny 17 . století. Tyto informace by měly vytvořit základnu pro další hudebně topografický výzkum nejen Krnova, ale i Slezska a Moravy.

1 HORYNA, Martin. Hudba a hudební život v Českém Krumlově do poloviny 16. století. In Miscellanea musicologica XXXI, 1984, s. 265-306.

2 BAŤA, Jan. Hudba a hudebni kultura na Starém Městě pražském 1526-1620. Disertační práce FF UK, Praha 2011.

MAŇAS, Vladimír. Hudba v Hlučíně v období raného novověku. In Opus musicum, Brno: Opus musicum, 2002, roč. 34, č. 5, s. 4-12.

$4 \quad \mathrm{Z}$ muzikologických prací zabývajících se Krnovem jmenujme např. diplomovou práci $H u$ debniny dochované na faře chrámu sv. Martina v Krnově Zory Gogelové z roku 1995 reflektující hudební dění převážně v 19. století. O Krnově pojednává také slovníkové heslo v Slovniku české hudebni kultury a Lexikon zur deutschen Musikkultur: Böhmen, Mähren, Sudetenschlesien, avšak oba příspěvky se věnují především varhanářství. Na dění za vlády Hohenzollernů se zaměřuje několik publikací Radka Fukaly např. Náboženství a protestantské školství za krnovského knižete Jiřiho Friedricha. V jeho studiích však často nejsou uvedeny odkazy na prameny, což znesnadňuje další práci s daným materiálem, který by mohl obsahovat cenné poznámky ke školní i hudební praxi. 


\section{Ve službách církve}

První zmínka o Krnově se váže k založení fary v roce 1221 . V listině krále Václava z roku 1240 se objevuje označení Kyrnow. ${ }^{5}$ Roku 1316 bylo Krnovu uděleno právo výročního trhu $\mathrm{v}$ den Nanebevzetí Panny Marie, což mu přidalo na důležitosti $\mathrm{v}$ rámci regionu. ${ }^{6}$ Pro chrámovou hudbu je podstatná př́tomnost školy, která je v Krnově doložena od roce 1415. Zaměstnáni zde byli kantor, succentor ${ }^{7}$ i pomocníci, kteří pečovali o kostelní zpěv. $\mathrm{V}$ této době byla založena i první fundace ve městě. ${ }^{8}$ Úkolem učitele bylo především, ,aby ve škole učil děti s největši pilí, ty samé vést se vš́ dobrotou k umění, kázni, poctivosti a dobrým mraviom."9

S klášterem minoritů, založeném okolo r. 1273, je spojeno fungování konventního kostela Nanebevzetí Panny Marie. Na počátku 15. století se do krnovského kláštera uchýlil Mikuláš z Kozlí, františkán a kazatel. ${ }^{10} \mathrm{~V}$ jeho zápisníku z let 1416-1417 jsou zaznamenány jedny z nejstarších hudebních památek slezské provenience. Mezi skladbami se nachází i Credo v motetovém stylu. Dále se v rukopise odráží rozvoj ars nova - obsahuje vícehlasé duchovní skladby, jako jsou Pulchrum evangelium, aleluja $O$ mestorum consolatrix s invokací k nejsvětější Panně Marii a nazývá ji Musicorum excitatrix. ${ }^{11}$ Tyto i další skladby zaznamenané Mikulášem z Kozlí poukazují na hudební praxi ve Slezsku. Je možné se domnívat, že ačkoli se nedochovaly přímé hudební památky z Krnova, odrážejí typologicky tamější praxi.

V Krnově, stejně jako v nedalekých Hlubčicích fungovalo od r. 1475 bratrstvo Božího Těla založené místním farářem. Se změnou majitele města a vlivem reformace se změnila náboženská př́slušnost farnosti na evangelickou. Roku 1524 protestantský majitel panství Jiří Braniborský odebral farní patronát německému řádu, zrušil bratrstvo Božího Těla a o rok později uzavřel také minoritský klášter. Ve městě byla zrrízena evangelická konzistoř, do které přichází nedlouho potom, v r. 1535 kazatel mistr Achác vyhnaný z Opavy. ${ }^{12}$

5 Srov. PRASEK, Vincenc. Historická topografie země Opavské. Opava: Vlastivěda slezská II, 1889, s. 493.

6 Ibid., s. 495.

7 podzpěvák

8 Srov. PRASEK, Vincenc. Historická topografie země Opavské. Opava: Vlastivěda slezská II, 1889, s. 514.

$9 \quad$ „daß der Lehrer die Kinder in der Schule mit allem Fleiße lehren und daß sie dieselben mit aller Güte zu den Künsten, zur Zucht, Ehre und guter Sitte anhalten."; SCHULIG, Heinrich. Ein Heimatbuch für die Bezirke Jägerndorf u. Olbersdorf. Troppau: Dreschler, 1923, s. 207.

10 Srov. PRASEK, 1889, op. cit., s. 512.

11 Srov. MUSIOL, Karol. Rozvoj slezské hudby umělé od stredověku do klasicismu. In ČSM, serie B, 1973, č. 2, s. 104.

12 Srov. WOLNY, Gregor. Kirchliche Topographie von Mähren, meist nach Urkunden und Handschriften. Brünn: Selbstverlag, 1863. s. 360. 
Škola i kostel formovaly smýšlení obyvatel, proto byly jako faráři a učitelé povolávány muži s odpovídajícím věroučným vzděláním. Na začátku panování Jiřího Braniborského byly školy v Krnově a Hlubčicích povýšeny na vyšší městské školy (latinské školy), na kterých se vyučovala kromě náboženství a trivia i hudba. ${ }^{13} \mathrm{~V}$ roce 1566 bylo vydáno Jiřím Friedrichem, markrabětem braniborským, povolení vydat ročně kostelnímu a školnímu sluhovi obilí (dvě měřice žita a dvě měřice pšenice) a dostatek dřeva, které musí městská rada ročně vyplatit. ${ }^{14} \mathrm{~V}$ pramenech z tohoto roku se nachází první zmínka o nově ustanoveném úr̆adu superintendenta, který měl na starosti pravidelné vizitace fary a školy. Krátce na to dochází ke zř́zení soukromé německé školy v roce $1567 .{ }^{15} \mathrm{Z}$ rozkazu markraběte Jiř́ího Friedricha bylo farám na Krnovsku 1586 posláno 20 tištěných katechismů pro výuku žáků. ${ }^{16}$

Po událostech z roku 1622 prripadl Krnov jako konfiskát do majetku kníže Karla Lichtenštejnského. Ten se snažil obnovit ve městě katolické uspořádání, r. 1623 byl klášter navrácen minoritům a za finanční pomoci města obnoven. ${ }^{17}$ Při klášteře pak bylo založeno 1668 bratrstvo sv. Františka fungující do 1815 jako konfederace 300 osob. Zuber udává, že majetek bratrstva byl ve výši 10000 zl., $\mathrm{z}$ toho byly placeny denně dvě mše za zemřelé, pohřby chudých členů, podpora nemocných a uhrazeny čtyři slavnostní bohoslužby ročně. ${ }^{18}$ Roku 1680 bylo obnoveno i bratrstvo Božího Těla při farním kostele Narození Panny Marie. ${ }^{19}$

Změna majitele panství se odrazila i v provozu školy, jelikož škola fungovala jako účinný prostředek pro změnu náboženské př́íslušnosti měštanů. Četné instrukce regulovaly náboženskou př́slušnost poddaných, resp. postihovaly perzekucemi nekatolické obyvatelstvo. $Z$ mnoha nařízení jmenujme např. povinnost odevzdat všechny výtisky Bible, kázání a kancionálů knížecímu soudci do Vánoc roku $1633 .{ }^{20}$ Podle téže instrukce mělo být zajištěno, aby ve školách vyučovaly vhodné osoby, a to minimálně jeden kantor a dva pomocníci, kteří měli dostávat včas náležitý plat. Zároveň se tímto zakazuje provoz všech škol, které nejsou zaštítěny farářem a městskou radou. ${ }^{21}$ Ve speciální vyhlášce týkající se církevních obřadů stojí z muzikologického hlediska za pozornost nařízení pro faráře.

13 Srov. SCHULIG, 1923, op. cit., s. 137.

14 Státní okresní archiv Bruntál (SokA Bruntál), fond Archiv města Krnova, kart. 1, i. č. 832, sign. 40: Povolení Jiř́iho Friedricha, 1566.

Srov. PRASEK, 1889, op. cit., s. 515.

16 Ibid., s. 515.

17 Srov. WOLNY, 1863, op. cit., s. 360.

18 SokA Bruntál, Farní Úřad Krnov, inv. č. 55: účty Bratrstva Kristova 1771-1782; též ZUBER, Rudolf. Osudy moravské církve v 18. století. II. Olomouc: Matice cyrilometodějská, 2003.

19 Zemský archiv v Opavě, pob. Olomouc, fond Arcibiskupská konzistoř (ACO), kniha č. 188: Děkanská matrika Krnov.

20 Srov. LÖSCHE, Georg. Zur Gegenreformation in Schlesien. Leizpig: Verein für Reformationsgeschichte, 1915. s. 169.

21 Srov. LÖSCHE, 1915, op. cit., s. 171. 
„[Farár $]$ je povinen zabránit učiteli chodit spolu s chlapci do márnice, aby tam zpivali a aby zato vybirali $\mathrm{mzdu}$.“22

\section{Varhany}

První doklad o prŕtomnosti varhan v Krnově je z roku 1640 - v matrice pokřtěných je jako kmotr zapsán Organist Georg Erner. Rok později 1641 nechá křtít svou dceru Annu Marii Organist Matheus Maxmilian Sperling. ${ }^{23}$ Tyto dva údaje mají zásadní význam, jelikož Wolny zmiňuje stavbu nových ve farním kostele $\mathrm{v}$ roce 1655 . Po šestnácti letech se objevují v kostelních účtech záznamy o vyplacených penězích pro varhanáře (Orgelsetzer) - v listopadu 1671 obdržel obnos 20

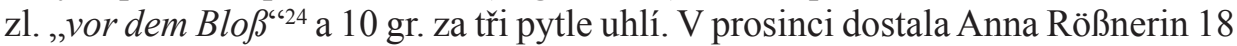
gr., jelikož poskytla varhanáŕi světnici, ve které mohl „Balken leimen“, Friedrich Fieck obdržel 13 gr. a $6 \mathrm{~d}$. za hrnce, které na to varhanář potřeboval. Po tomto výčtu následuje položka $5 \mathrm{zl}$. pro varhanáře za opravu varhan. Na počátku roku 1672 byly proplaceny následující položky - varhanáři 22 zl. 36 gr., za dvakrát půl vědra piva 36 d. (halbes Eymerbier à 18 d.) a 15 d. za klášterní dřevo. V květnu byly zaplaceny za hřebíky pro stavbu varhan 3 gr. 6 d. a varhanáŕ dostal 12 zl. 18 gr. „,vor ein Regal mit einem Flätten.“ Děkan při vizitaci varhan ocenil varhanáře navíc 28 gr. za odvedenou práci.

V děkanské matrice z roku 1672 jsou zmíněny varhany, o dalších hudebních nástrojích v majetku farnosti zde ale nepíše. Vedle farního kostela fungoval i hřbitovní kostel, který byl nazýván českým kostelíkem. ${ }^{25} \mathrm{Na}$ jeho provoz přispívalo město a městská rada. Podle této děkanské matriky se v tomto kostele nacházelo velké množství hudebnin a hudebních nástrojü. ${ }^{26}$ Roku 1680 vedle farní školy fungovalo také gymnasium, kde vyučovali rektor, kantor a varhaníci, které vydržovala městská rada. ${ }^{27}$

22, ,[Der Pfarrer] verhindert den Schulmeister mit den Schulknabem zum Leichenhause zu gehen, um zu singen und ihre Gebühr zu erhalten.", LÖSCHE, 1915, op. cit., s. 252.

23 Zemský archiv v Opavě, fond Matriky, i. č. 807, sign. Kr I 1: Krnov 1640-1674.

24 Zřejmě označení pro klíh; Státní okresní archiv Bruntál, fond Farní úřad Krnov, i. č. 14, sign. II/c: Kniha kostelních účtů 1671.

25 „böhmische Kirchel“, tento kostel zanikl v době Josefínských reformací.

26 Pravděpodobně vychází z: Inhaeret muro superiori magnum pneumaticum Organum, satis pulchrum et bonum, adjuncto eidem musicali choro amplo. Zemský archiv v Opavě, pob. Olomouc, fond Arcibiskupská konzistoř (ACO), kniha č. 188: Děkanská matrika Krnov, 1672. Informaci přejímá i děkanská matrika 1691. 


\section{Hudebníci ve službách kostela}

První doklad chrámové provozovací praxe v Krnově představuje popis zpěvu, který vedl od r. 1534 do února 1535 kazatel mistr Achác, který ŕídil kostelní zpěv, první sloku zpívali žáci a druhou sloku lid, tj. ve stylu praxe alternatim. ${ }^{28}$

$\mathrm{Na}$ hudebním provozu kostela se podílela mnoho osob, stejně tak tomu bylo i v Krnově. V matrikách, archivních materiálech i literatuře najdeme celou řadu jmen titulovaných jako Schulmeister, Schulhalter, Rector, Cantor a Organist. Běžnou praxí bylo nejen zapojení těchto zaměstnanců školy, ale také školních dětí - převážně chlapců. Důraz na hudební vzdělání ve školních ráádech odrážel praktickou potřebu hudebního doprovodu mší.

V Krnově fungovala škola triviální a škola latinská, o čemž vypovídají informace o kantorech. Ze sekundárních pramenů je však možno vysledovat jména mnoha učitelů. V latinské školy vyučoval Leonarda Hambergra z Ingolstadtu, který v Krnově působil v letech 1555-1560, dále zde byl mezi léty 1563 až 1568 činný jako cantor Magnus Jahn. ${ }^{29}$ Od roku 1565 se ve větší míře na postech vyučujících objevují vzdělané osoby z nedalekých lokalit. Prvním rektorem byl magister Baltazar Seckenberg z Opavy,$^{30}$ na jehož místo posléze nastoupil bakalář Bartoloměj Golde (Chrysäus), přicházející taktéž z opavské latinské školy. Další bakaláŕ Kryštof Tscheuschner působil v Krnově od r. 1572, později odešel do Hlubčic na post pastora. ${ }^{31}$ Tento kariérní postup byl, jak lze z pramenů i z následujícího textu vysledovat, pro luteránské prostředí obvyklý. Hodiny reformního náboženství vyučovali v Krnově tzv. Kirchenlehrer - Mag. Johann Volckmann, Johann Leuthner a David Schwertner. ${ }^{32}$

Roku 1577 v Krnově učil magister Georg Eising, syn kazatele v Kladské Bystřici, ${ }^{33}$ který byl označován jako Schullehrer. ${ }^{34}$ Doktor medicíny a filozofie Matěj Unger z Opavy zastával funkci školního mistra - Schulmeister - mezi léty 1577 až $1584 .{ }^{35} \mathrm{Na}$ jeho místo nastoupil Georg Reymann z Hlubčic, od roku 1596 pak zastával tento post krnovský rodák Josef Luckner. ${ }^{36}$ Krátce zde v roce 1601

28 Srov. WOLNY, 1863, op. cit., s. 360.

29 Předchozí působiště jako kantor - Prudník, po krnovském působení kantor v Bílovci (srov. FUKALA, Radek. Náboženství a protestantské školství za krnovského knižete Jiřiho Friedricha. In Sborník bruntálského muzea Bruntál: Muzeum v Bruntále, 2000. s. 31).

Později se stal pastorem v Jeseníku a v Suchdole nad Odrou.

Srov. FUKALA, 2000, op. cit., s. 31.

Srov. FUCHS, Gottlieb. Materialien zur evangelischen Religionsgeschichte von Oberschlesien. Breslau: Kron, 1774, s. 43-44.

P1 . Bystrzyca Kłodzka, něm. Habelschwerdt.

Srov. BACH, Alois. Kirchen-Geschichte Der Grafschaft Glaz: Von Der Urzeit Bis Auf Unsere Tage. Breslau: Gustav Fritz, 1841, s. 406.

Srov. FUKALA, 2000, op. cit., s. 31.

Srov. PRASEK, 1889, op. cit., s. 515. 
působil i Georg Kinnel z Žabčic u Hlubčic. ${ }^{37}$ Krnovský univerzitní mistr Martin Arnoldus byl ve svém rodišti rektorem v letech 1610 až 1612 a následně působil jako pastor v Žabčicích. ${ }^{38} \mathrm{O}$ dalším rectorovi Andreasi Ignatiu Hallmannovi ${ }^{39}$ je zmínka až v křestní matrice z roku 1642.

Záznamy o německé elementární jsou dochovány teprve od počátku 17 . století. Vyučující byli označování jako deutsche Schulhalter. Prvním známým učitelem je Jan Zillich, ${ }^{40}$ který zde vyučoval mezi léty 1606 až 1608 . Učitelem městské školy byl krátce na to Adam Erbius z Krnova, který byl též literárně činný napsal 17 elegických distichů. ${ }^{41}$ Po prodlevě, v roce 1691 je jako další teutsche Schulhalter označen Kristian Weigel. Ten si v dopise děkanskému úřadu stěžuje, že mu brání učit děti déle, než se naučí slabikovat. I přesto se městská rada zasadila o to, aby tato škola nezanikla. ${ }^{42}$

\section{Hudba jako reprezentace šlechty a města}

Krnovské knížectví přešlo roku 1523 do majetku Braniborsko-Ansbašské větve rodu Hohenzollernů, což také znamenalo počátek reformace na tomto území a nedlouho nato 1528 bylo zavedeno v knížectví luteránství. S tím souvisí vznik nových městských řádů, které mají usměrňovat chování měšt’anů - řád z roku 1551 zapovídal zejména ,noční tance, zvláště pak točivé - tímto tancem jest nejspišs ,ovad', kde tanečnice na jednom mistě se točí, přičemž sukně jí jsou jakoby křidly, a honivé - miněn jest nejspišse ,kot' “"43 Jiný nedatovaný městský rád udává, že ,pokud by se někdo o svatbě při tanci točil, zohýbal či skákal, propadne, nech žena, nech muž $12 \mathrm{gr}$. anebo na tři dni do klády přijde. Mladík tančící by se svlékl, propadne kabát a dán bude do vězeni. "“44 Regulace tance postihovala i svatební veselí, při kterém smělo tančit nanejvýše 24 párů najednou. Další instrukce se věnují pohřbům - nemá se chodit, jak stádo běží, ale nejprve muži a za nimi ženy, atd. ${ }^{45}$

V souvislosti s krnovským dvorem se také mluví o tzv. básnické humanistické škole, která dokládá, že Horní Slezsko včetně Krnova patřilo k dobovým

Srov. FUKALA, 2000, op. cit., s. 31.

Srov. MARTINEK, Libor. Latinská humanistická škola v 16. století na Krnovsku. In Sborník bruntálského muzea. Bruntál: Muzeum v Bruntále, 2003, s. 44.

Zemský archiv v Opavě, fond Matriky, i. č. 807, sig. Kr I 1: Krnov 1640-1674.

Srov. PRASEK, 1889, op. cit., s. 515.

Srov. MARTINEK, 2003, op. cit., s. 44.

PRASEK, 1889, op. cit., s. 515.

PRASEK, 1889, op. cit., s. 501.

Ibid., s. 501.

SCHULIG odkazuje na krnovskou hypotéční knihu z let 1574-1619, fol. 1-8. Srov. SCHULIG, Heinrich. Ein Heimatbuch für die Bezirke Jägerndorf u. Olbersdorf. Troppau: Dreschler, 1923. 
centrům vzdělanosti. Mnozí z protestantských kantorů, učitelů a kazatelů byli literárně činní. ${ }^{46} \mathrm{Na}$ dvoře v Krnově působil básník a skladatel duchovních písní, tzn. Kirchenliederdichter Martin Kinner von Scherffenstein, rodák z Hlubčic, který žil mezi lety 1534 až 1597. Na základě epitafu sepsaného Johannem Kasparem Wetzelem o něm víme, že byl 15 let činný jako syndicus a také, že působil dva roky jako sekretář v Krnově. ${ }^{47}$ Ve své době byl více oceňován jako učenec a hudební znalec, než jako básník. ${ }^{48}$ Dnes se o něm však dovídáme převážně z literárněvědných antologií.

Jeho hudební tvorbu můžeme rozdělit na německou písňovou tvorbu, publikovanou $\mathrm{v}$ kancionálech a latinskou motetovou tvorbu. Tiskem vyšlo několik jeho německých písní. Ve Varšavě jsou uloženy tisky dvou písní Martina Kinnera - jeden z nich, čtyřhlasá píseň Ein Christlich Betliedlein wider gemeinen Erbfeind den Türcken, ${ }^{49}$ je dedikován bruntálskému pastorovi Hieronymu Koschwitzovi. Do protestantského notovaného kancionálu „Geistlichen Kirchen- und Haus-Musik: Darinnen außerlesene Gesänge, Psalmen und Hymni, auf die gewöhnliche Sonn- und Festtage [...] mit vielen Geistreichen Gesängen nebst iihren Melodeyen." z roku 1644 bylo zařazeno osm jeho duchovních písní. Některé z nich jsou převzaty i do mladších kancionálů jako je tisk Müntzlla $\mathrm{z}$ roku $1855^{50}$ či Wackernagla z roku $1877 .^{51}$

Z hudebního hlediska jsou však zajímavějšími Kinnerovy latinské skladby, které jsou dochovány pouze $\mathrm{v}$ několika exempláŕích. Eitner uvádí jako jedinou publikaci Kinnera tisk Melodia Epithalamij quinque vocum. In gratiam illustr. Principis ac Dni. Dni. Wenceslai Ducis Silesiae etc. composita à M. Martino Kinnero Leobschucensi, $1567 .{ }^{52}$ Jeho dílo je však dochováno i v dalších lokalitách - na Slovensku ve sbírce z Kežmarku se ve třetí části konvolutu Carmen funebre nalézá Kinnerova Plangite Chrysorides ${ }^{53}$ zkomponovaná v mixolydickém modu.

46 O tomto tématu více: MARTINEK, Libor. Latinská humanistická škola v 16. století na Krnovsku. In Sbornik bruntálského muzea. Bruntál: Muzeum v Bruntále, 2003. s. 41-52. a v publikaci TRUHLÁR̆, Antonín. HRDINA, Karel. HEJNIC, Josef a MARTÍNEK, Jan. Rukovět humanistického básnictví v Čechách a na Moravě: Enchiridion renatae poesis Latinae in Bohemia et Moravia cultae. Praha: Academia, 1966-2011, 6 sv.

47 Sekretär in Carnow; srov. EITNER, Robert. Kinner von Scherffenstein, Martin. In Allgemeine Deutsche Biographie. Leipzig: Duncker \& Humblot, 1882. B. 15, S. 770.

Srov. KAHLERT, August. Schlesien Antheil an Deutscher Poesie: Ein Beitrag Zur Literaturgeschichte. Breslau: A. Schulz, 1835, s. 25.

49 Katalogizační záznam. Digitální knihovna Vratislavské univerzity. Universitet Wroclawski [online]. 2015. [cit. 2015-08-15]. Dostupné z:

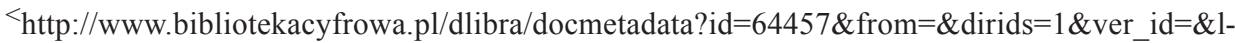
$\mathrm{p}=2 \& \mathrm{QI}=086 \mathrm{~A} 6 \mathrm{BA} 2 \mathrm{~B} 471 \mathrm{FAE} 0 \mathrm{~F} 9 \mathrm{~B} 1697 \mathrm{BF} 5 \mathrm{~B} 575 \mathrm{AC}-3>$.

51 WACKERNAGEL, Philipp. Das deutsche Kirchenlied von der ältesten Zeit bis zu Anfang des XVII. Jahrhunderts. Leipzig: Teubner, 1877. Bd. 5, S. 295 ff.

53 SK-KE, sign. N 69 192, www.rism.info, ID no. 570006038. 
Celý konvolut je dedikován Valentinu Friedlandovi zvaném Trozendorf, rektorovi školy v dolnoslezském Goltperku. ${ }^{54}$

V rukopisné hlasové knize ${ }^{55}$ uložené v Dražd’anech je bílou menzurální notací zaznamenán basový part moteta Viri diligite uxores vestras, který se nalézá v konvolutu 106 motet. Totéž moteto je součástí hlasových knih vytištěných v Norimberku. ${ }^{56}$ Norimberský tisk obsahuje také další tři Kinnerova moteta Dum nova solenni dum nova solennem, Qui celebrans quondam sponsalia, Semper honorabile sit conjugium. ${ }^{57}$ Tato čtyři Kinnerova latinská moteta mají společné ústřední téma - uzavření sňatku a texty, které nejsou zcela tradičně zhudebňovány.

Zhudebnění textu Viri diligite uxores vestras z 5. kapitoly listu Efeským není v motetové tvorbě obvyklé. ${ }^{58} \mathrm{Na}$ základě přepisu tří dochovaných hlasů $(\mathrm{A}, \mathrm{T}$, B) $)^{59}$ je možné alespoň částečně přiblížit Kinnerův kompoziční styl. Moteto otevírá úvodní motiv procházející všemi hlasy. Také každá nová textový fráze je uvedena novým motivem, který vždy jedenkrát prochází všemi hlasy, ale dále již opakován není. V tř́hlasém torzu inklinují souzvuky k jasné harmonii.

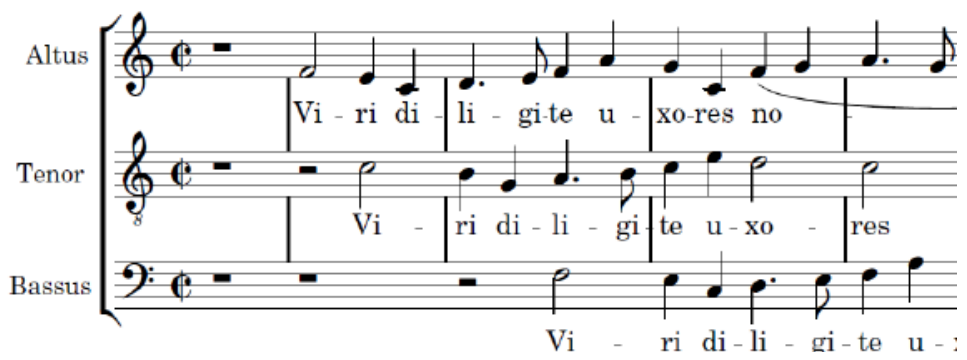

Obr. 1. Viri diligite uxores nostra - úvodní imitace

Tvorba Martina Kinnera von Scherffenstein zasluhuje pozornost nejen proto, že je jedním z mála známých skladatelů, kteří působili i v Krnově, ale také proto, že se jeho díla vyskytují ve sbírkách vedle děl Josquina de Prés, Jacoba Handla Galla, Clemense non Papa, Johanna Knefelia či Orlanda di Lassa.

Na počátku 17. století přešlo panství do správy Jana Jiř́ho Krnovského, ${ }^{60}$ posledního majitele z rodu Hohenzollernů, který byl jedním z významných před-

\footnotetext{
54 pl. Złotoryja, něm. Goldberg

55 D-DI, sign. Mus.1-D-6, www.rism.info, ID no. 211002604.

56 Datum vydání tisku je stanoveno okolo $\mathrm{r}$. 1500, což je více než nepravděpodobné.

57 D-Mbs, sign. Mus.pr. 53, www.rism.info, ID no. 00000993108822.

58 Krom Kinnerova zhudebnění se v databázi RISM nachází tentýž text u moteta připsaného Johannovi Wirckerovi.

59 Tenorová hlasová kniha je dochována pouze jako mladší opis vevázaný v původních deskách.

60 Johann Georg von Jägerndorf, označován též jako Johann Georg von Brandenburg.
} 
stavitelů české nekatolické šlechty. Na krnovském zámku uspořádal r. 1610 pětidenní oslavu svého sňatku s princeznou Evou Christinou, dcerou vévody Friedricha Württemberského ${ }^{61}$ Př̀i této prŕležitosti Krnov navštívili, mino jiné vévoda z Württembergu, markrabě Friedrich Braniborský či zástupci české šlechty. Pro zábavu této společnosti proběhly mnohé okázalé průvody, tance, rytî̌ské hry, hostiny, hody a ohňostroje, ${ }^{62}$ což odkazuje také k prŕtomnosti hudebníků při této slavnostní př́ležitosti. Detailněji se dochovaly zprávy o představení hesenských komediantů, kteří se měli nejdř́ve zdržovat v Praze u dvora Rudolfa II. a od 1. května 1610 v Krnově. V rámci svatebních oslav 6. června po večeři zahráli Komedii o Amadisovi, další představení následovala 9. a 10. června. ${ }^{63}$

Ač starší literatura odkazuje na pramen, ve kterém by mělo být svatební veselí popsáno blíže, nebylo možné jej v současné době dohledat. Avšak na základě stížnosti olomouckého varhaníka z konce 16. století lze alespoň rámcově hudební dění během měštanských svateb zrekonstruovat. Svatební průvod do kostela a následně z něj byl doprovázen zvukem trompet a pozounů. Slavnostní tabule byly doprovázeny pouze hrou na clavichord. ${ }^{64}$ Vezmeme-li v úvahu, že se v Krnově nejednalo o svatbu měšt’anskou, ale šlechtickou, která byla politicky významná, převyšovalo zřejmě hudební obsazení standart své doby. Nadstandartní poměry dokládá i přítomnost již zmíněné divadelní společnosti. Je také nutno vzít v úvahu př́tomnost bývalého lichtenštejnského kapelníka Zangia, který posléze zastával pozici kapelníka v Berlíně na dvoře bratra Jana Jiřího Krnovského. ${ }^{65}$

Po této prestižní události začal upadat význam Krnova jako kulturního a mocenského centra, což souviselo i s událostmi z roku 1622, kdy přidalo krnovské panství knížeti Karlu Lichtenštejnskému. ${ }^{66}$

\section{Městští trubači}

$\mathrm{K}$ reprezentaci města $\mathrm{v} 16$. století patřili trubači. V aktových materiálech jsou označováni rozličnými pojmy - Turmbürger, Pfeifer, Stadtpfeifer a Musicus instrumentalis. Úřad trubače $\mathrm{v}$ Krnově s sebou nesl povinnost zajišt’ovat stráž

61 Srov. PRASEK, 1889, op. cit., s. 503.

62 Srov. SCHULIG, 1923, op. cit., s. 221.

63 Srov. POLOCHOVÁ, Markéta. Ozvuky anglického divadla a dramatu v raně novověké epoše na evropském kontinentu: anglické cestujici společnosti. [online]. Brno, 2015 [cit. 2015-0920]. Disertační práce. Masarykova univerzita, Filozofická fakulta. Vedoucí práce Eva Stehlíková. Dostupné z: <http://is.muni.cz/th/75090/ff_d/>. s. 62-63.

Srov. SCHLUSCHE, Herbert. Stadtpfeifer und Instrumentenbauer in Olmütz im 16. Jahrhunderts. Praha, 1942. Disertační práce. Karlova univerzita, Filozofická fakulta. s. 10.

65 Srov. MAŇAS, Vladimír. Tušení souvislostí. Hudba na dvoře Karla I. z Lichtenštejna na počátku 17. století ve středoevropském kontextu. In Časopis matice moravské, Brno: Matice moravská, 2013, roč. 132, 5 suppl., s. 127-137. 
ve věži městské brány a kostela. ${ }^{67}$ Pravděpodobně nejstarší poznámka o krnovském trubači se dochovala v olomouckém kopiárí z roku 1510. Herbert Schlusche odkazuje na listinu, kde je vedle jména Jan Trompeter (trubacz) napsaná Anna Spielmannin (hudcowa) z Krnova. ${ }^{68}$

O trubačích za správy rodu Hohenzollernů svědčí krom úředních nařízení také dopis z roku 1553, kterým se o místo trubače v Olomouci ucházel krnovský městský trubač Georg Schmidt. V dopise městské radě z 9. prosince 1553 píše, že je činný jako samo čtvrtý, má dobrého hráče na cink a tovaryše Veittela, tovaryše hrajícího na všelijaké nástroje, který byl předtím mistrem v Nise. ${ }^{69}$ Schmidt nabízí olomouckým radním hru na zkoušku, přičemž se prezentuje výčtem hudebních nástrojůn, které má ve svém vlastnictví a přiveze je s sebou do Olomouce: „krumb horner, schalmehen, Posaunen, Pommern und fledten.“70 Jako zdůvodnění své žádosti se odvolává nato, že mu olomoučtí kupci dali najevo, že se smí o tuto pozici ucházet. Jako nespornou výhodu uvádí fakt, že v Olomouci nemůže být považován za cizince, jelikož tam sloužil jeden rok jako tovaryš trompetista a oženil se v té době s dívkou z Olomouce. Schmidt se však olomouckým trubačem nestal, pravděpodobně se dokonce neuskutečnilo ani jeho setkání s městskou radou v roce 1544. Dedukce těchto informací je možná na základě dopisu niského trubače mistra Jörga, který píše, že Georg Schmidt měl již dříve prrislíbené místo městského trubače v Olomouci, ale dal přednost stejné pozici v prestižnější lokalitě, v Nise. Olomoučtí radní však o tomto rozhodnutí nevěděli a odmítli lineckého trubače Leonharda Khünbergra. O šest let později se v olomouckých pramenech nachází poslední zmínka o osudu krnovského trubače Schmidta, v níž je označen jako městský trubač v Opavě. ${ }^{11}$

Dále prameny i literatura o městských trubačích v Krnově mlčí až do roku 1625, ve kterém byl za měšt’ana přijat musicus Hans Neumann. Z roku 1626 se dochovaly záznamy o městském trubači Tobiasi Reimanovi, který měl na věži před příchodem dánských vojsk vyvěsit bílý prapor, aby město nebylo zničeno. Za toto jednání byl obviněn. Při trestání provinilých o tř̆ léta později je již titulován jako trubač v Malém Hlohově. ${ }^{72}$ Mezi roky 1650 až 1664 zastával tento úřad Hans Kircher, který byl hrdelním soudem odsouzen v toce $1650 \mathrm{k}$ trestu smrti, jelikož zastřelil svého tovaryše Bonaventuru. $V$ té době měl ještě druhého tovaryše Jiřího Erta. Po několika letech byl Kircher zproštěn rozsudku a vykonával dále svou funkci. Od r. 1665 je jako městský musicus instrumentalis označován Christian Heinisch, který je též zaznamenán v kostelních účtech v let 1671

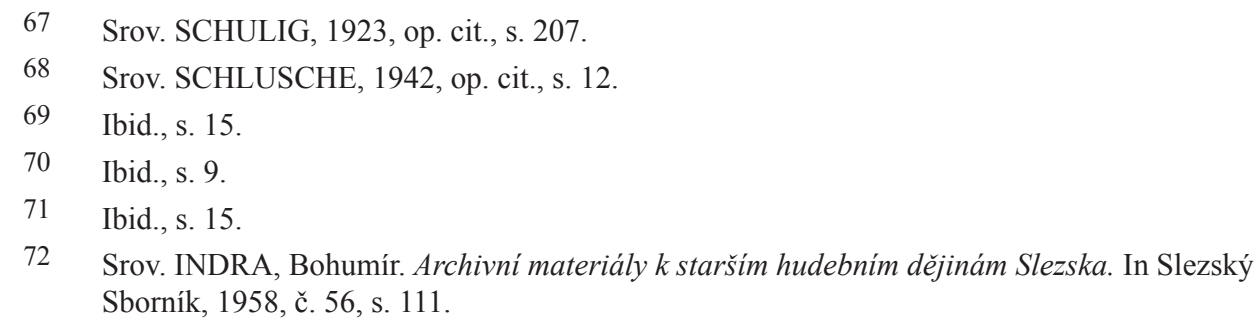


a 1672. Za hraní dostal Stadtpfeifer od farnosti 1 zl. 9 gr. V roce 1675 jej vystř́ídal Šimon Jan Bieschel. ${ }^{73}$

\section{Závěr}

Při mapování městské hudební kultury dané lokality se paralelně dozvídáme o hudebním životě měst, které byly vzájemně politicky či geograficky propojeny. Tímto způsobem lze zaplňovat pomyslná bílá místa $\mathrm{v}$ hudebnách dějinách měst i v případě, že se tamější hudebniny ani nehudební aktový materiál nedochoval.

Hudební dějiny Krnova odráží proměny v náboženských poměrech panství. $\mathrm{Na}$ základě pramenů a literatury se podařilo sestavit soupis kantorů a trubačů působících v Krnově od poloviny 16 . stol. do roku 1672 . Z nich vyplývá propojení nedalekých slezských měst Opavy, Krnova a Hlubčic. Mnozí z dosazovaného personálu, hudebníci i kantoři přecházeli z jednoho města do druhého z důvodu kariérního postupu. Ačkoliv nejsou z Krnova dochované žádné hudební památky, lze na základě nehudebních pramenů konstatovat, že v období renesance zde byl bohatý hudební provoz jak v církevním, tak sekulárním prostředí.

Helena Kramářová (helena.kramarova@gmail.com), Ústav hudební vědy, Filozofická fakulta, Masarykova univerzita, Brno, CZ.

\section{ABSTRACT \\ MUSICAL CULTURE IN KRNOV TILL SECOND HALF OF THE SEVENTEENTH CENTURY}

The focus of this paper is on musical culture of Krnov during Renaissance, because the musicologists haven't turned attention to this subject yet. The list of schoolmasters, organists and trumpeters was reconstructed on the basis of source research and literature. We have discovered the first mention of the organ and the reparations, too. There is also a part about composer Martin Kinner von Schefferstein.

\section{Key words}

Krnov, Renaissance musical culture, schoolmasters, trumpeters, organ, Martin Kinner von Schefferstein

\section{Bibliography}

\section{Sources}

Státní okresní archiv Bruntál, fond Archiv města Krnova, i. č. 35: Městská kniha 1520-1802. 
Státní okresní archiv Bruntál, fond Archiv města Krnova, i. č. 36: Městská kniha 1544-1558.

Státní okresní archiv Bruntál, fond Archiv města Krnova, kart. 1, i. č. 832, sign. 40: Povolení Jiřího Friedricha, 1566.

Státní okresní archiv Bruntál, fond Farní úřad Krnov, i. č. 14, sign. II/c: Kniha kostelních účtů 1671. Státní okresní archiv Bruntál, fond Farní úřad Krnov, i. č. 15, sign. II/c: Kniha kostelních účtů 1672. Zemský archiv v Opavě, fond Matriky, i. č. 807, sig. Kr I 1: Krnov 1640-1674.

Zemský archiv v Opavě, pob. Olomouc, fond Arcibiskupská konzistoř (ACO), kniha č. 188: Děkanská matrika Krnov, 1672.

\section{Literature}

BACH, Alois. Kirchen-Geschichte Der Grafschaft Glaz: Von Der Urzeit Bis Auf Unsere Tage. Breslau: Gustav Fritz, 1841.

BAŤA, Jan. Hudba a hudební kultura na Starém Městě pražském 1526-1620. Disertační práce. Karlova univerzita. Filozofická fakulta. Praha, 2011.

EITNER, Robert. Kinner von Scherffenstein, Martin. In: Allgemeine Deutsche Biographie. Leipzig: Duncker \& Humblot, 1882, Bd. 15, S. 770 f.

FUCHS, Gottlieb. Materialien zur evangelischen Religionsgeschichte von Oberschlesien. Breslau: Kron, 1774.

FUKAČ, Jiří. Krnov. In: Fukač, Jiří - Macek, Petr - Vysloužil, Jiří (edd.) Slovník české hudebni kultury. Praha, 1997, s. 476.

FUKALA, Radek. Náboženství a protestantské školství za krnovského knižete Jiřiho Friedricha. In: Sborník bruntálského muzea Bruntál: Muzeum v Bruntále, 2000. s. 25-39.

HORYNA, Martin. Hudba a hudební život v Českém Krumlově do poloviny 16. století. In Miscellanea musicologica XXXI, 1984, s. 265-306.

INDRA, Bohumír. Archivni materiály k starším hudebním dějinám Slezska. In: Slezský Sborník, 1958, č. 56, s. 109-124.

KAHLERT, August. Schlesien Antheil an Deutscher Poesie: Ein Beitrag Zur Literaturgeschichte. Breslau: A. Schulz, 1835.

LÖSCHE, Georg. Zur Gegenreformation in Schlesien. Leizpig: Verein für Reformationsgeschichte, 1915.

MAŇAS, Vladimír. Hudba v Hlučíně v období raného novověku. In Opus musicum. Brno: Opus musicum, 2002, roč. 34, č. 5, s. 4-12.

MAŇAS, Vladimír. Tušení souvislostí. Hudba na dvoře Karla I. z Lichtenštejna na počátku 17. století ve středoevropském kontextu. In Časopis matice moravské, Brno: Matice moravská, 2013, roč. 132,5 suppl., s. 127-137.

MARTINEK, Libor. Latinská humanistická škola v 16. století na Krnovsku. In Sborník bruntálského muzea. Bruntál: Muzeum v Bruntále, 2003. s. 41-52.

MUSIOL, Karol. Rozvoj slezské hudby umělé od středověku do klasicismu. In: ČSM, serie B, 1973/2, s. 97-117.

MÜNTZELL, Julius. Geistliche Lieder der evangelischen Kirche aus dem sechszehnten Jahrhundert: Nach den ältesten Drucken. Berlin: Euslin, 1855.

POLOCHOVÁ, Markéta. Ozvuky anglického divadla a dramatu v raně novověké epoše na evropském kontinentu: anglické cestující společnosti. [online]. Brno, 2015 [cit. 2015-09-20]. Disertační práce. Masarykova univerzita, Filozofická fakulta. Vedoucí práce Eva Stehlíková. Dostupné z: $<$ http://is.muni.cz/th/75090/ff_d/>.

PRASEK, Vincenc. Historická topografie země Opavské. Opava: Vlastivěda slezská II, 1889.

SCHLUSCHE, Herbert. Stadtpfeifer und Instrumentenbauer in Olmütz im 16. Jahrhunderts. disertace Univerzity Karlovy, Praha, 1942.

SCHULIG, Heinrich. Ein Heimatbuch für die Bezirke Jägerndorf u. Olbersdorf. Troppau: Dreschler, 1923. 
TROJAN, Jan. Kantoři na Moravě a ve Slezsku v 17. - 19. století: jejich sociální postavení, společenská funkce a význam ve vývoji národni hudebni kultury. Brno: Muzejní a vlastivědná společnost, 2000.

TRUHLÁŘ, Antonín. HRDINA, Karel. HEJNIC, Josef a MARTÍNEK, Jan. Rukovět humanistického básnictví v Čechách a na Moravě: Enchiridion renatae poesis Latinae in Bohemia et Moravia cultae. Praha: Academia, 1966-2011.

WACKERNAGEL, Philipp. Das deutsche Kirchenlied von der ältesten Zeit bis zu Anfang des XVII. Jahrhunderts, Leipzig: Teubner, 1877.

WOLNY, Gregor. Kirchliche Topographie von Mähren, meist nach Urkunden und Handschriften. Brünn: Selbstverlag, 1863.

ZUBER, Rudolf. Osudy moravské cirkve v 18. století. II. Olomouc: Matice cyrilometodějská, 2003. 
